\title{
Efficacy of colour doppler imaging in prediction of placenta accrete
}

\section{Rachna Agarwal $^{1 *}$, Shruti Bhaskaran ${ }^{1}$, Esha Gupta1, Dipanvita Dutta ${ }^{1}$, Anupama Tandon ${ }^{2}$}

${ }^{1}$ Department of Obstetrics and Gynecology, ${ }^{2}$ Department of Radiology, University College of Medical Sciences and Guru Teg Bahadur Hospital, Delhi, India

Received: 28 July 2017

Accepted: 22 August 2017

\section{*Correspondence:}

Dr. Rachna Agarwal,

E-mail: rachna_anila@yahoo.co.in

Copyright: ( $)$ the author(s), publisher and licensee Medip Academy. This is an open-access article distributed under the terms of the Creative Commons Attribution Non-Commercial License, which permits unrestricted non-commercial use, distribution, and reproduction in any medium, provided the original work is properly cited.

\section{ABSTRACT}

Background: In present scenario of increasing cases of previous caesarean section the diagnosis of Placenta accreta preoperatively is of great value to the attending obstetrician. This helps in preparing, counselling the patient and also in assembling a multidisciplinary team for effective peripartum clinical management of these patients to prevent maternal morbidity and mortality.

Methods: One hundred patient with persistent placenta previa after 28 weeks gestation were screened by grey scale B mode sonography. In suspicious cases of placenta accreta, further assessment by colour Doppler ultrasound was done. The color doppler imaging (CDI) criteria used were - diffuse intra parenchymal placental lacunar flow, focal intra parenchymal placental lacunar flow, bladder-uterine serosa interphase hypervascularity, prominent sub-placental venous complex and loss of sub-placental vascular signal in areas lacking peripheral sub-placental hypoechoic zone. Patients were prospectively followed up till delivery and the CDI findings were analysed with reference to final diagnosis made during caesarean section.

Results: Six of hundred patients exhibited characteristic CDI patterns highly specific for placenta accreta according to the criteria used. In all 6 patients, morbidly adherent placenta was present intraoperatively. The sensitivity and specificity of CDI in the diagnosis of placenta accreta in presentstudy was $100 \%$. Caesarean hysterectomy was required in five patients. Patients with CDI features of lacunar flow had higher incidence of blood loss, transfusion requirements and need for caesarean hysterectomy compared to patients with nonlacunar flow. The remaining 94 patients with placenta previa, not suspicious for placenta accreta on sonography underwent uncomplicated caesarean section.

Conclusions: The use of CDI along with conventional grey-scale sonography improves the diagnostic accuracy for prediction of placenta accreta in patients with persistent placenta previa.

Keywords: Colour Doppler, Placenta previa, Placenta accrete, Ultrasound

\section{INTRODUCTION}

Placenta previa is a common complication of pregnancy occurring in approximately 1 in 200-250 births. ${ }^{1}$ Placenta accreta, strongly associated with placenta previa, is a rare but potentially life threatening complication of pregnancy and it is one of the major causes of massive obstetric haemorrhage and a major indication for peripartum hysterectomy. ${ }^{1}$ With the increasing rate of caesarean delivery, the incidence of both placenta previa and placenta accreta is steadily increasing, the risk of latter increasing significantly with consecutive caesarean sections. ${ }^{2,3}$ The complications of placenta accreta are significant and include risk of maternal death due to severe haemorrhage, as well as damage to the uterus, bladder and bowel. These complications can be managed 
with prior knowledge of the underlying condition and requires a multidisciplinary approach including provision of blood products, interventional radiology, appropriate surgical and anaesthetic cover, as well as intensive care facilities. Hence its antenatal diagnosis is essential. Our ability to diagnose placenta accreta has changed over the last decade and a high index of suspicion and experience has increased our chance to make a correct diagnosis. The antenatal detection rate of placenta accreta (a collective term for accreta, increta and percreta) on ultrasound varies in the literature, ranging from $33 \%$ to $100 \% .^{4,5}$ The Gray-scale sonography has been shown to be an excellent tool, with a sensitivity reported in the range of $77 \%$ to $87 \%$, specificity of $96 \%$ to $98 \%$, a positive predictive value (PPV) of $65 \%$ to $93 \%$, and a negative predictive value (NPV) of $98 \% .^{6}$ The use of colour Doppler and/ or power Doppler has been reported to improve the sensitivity and specificity of grey scale ultrasound..$^{5,7,8} \mathrm{We}$ conducted this study with the aim to evaluate the efficacy of colour Doppler imaging in the prediction of placenta accreta in the antenatal period and maternal and perinatal outcome of this dreaded condition.

\section{METHODS}

This prospective study was conducted in the Department of Obstetrics and Gynecology and Department of Radiology. A total of 100 patients were enrolled over a period of one year. Patients who were hemodynamically stable and presented with diagnosis or suspicion (based on history) of placenta previa after 28 weeks of gestation and persisted to have partial or total placenta previa were included in the study.

Prior obstetric history was noted in terms of number of previous caesarean section, $\mathrm{D}$ and $\mathrm{C}$ and other gynaecological surgeries. Gray scale B- mode sonography was first used to screen the placental tissue in a systematic fashion. Careful attention was paid to homogeneity and echogenicity patterns of the placenta. Criteria suggestive of placenta accreta that were assessed included the following.

- Loss of normally visible retroplacental hypoechoic zone.

- Presence of multiple lakes that represent dilated vessels extending from placenta through the myometrium, the so called 'Swiss cheese' appearance of placenta.

- Thinning or focal disruption of the uterine serosabladder wall complex.

- Focal mass like elevation of tissue with the same echogenicity of the placenta beyond the uterine serosa.

In cases suspicious of placenta accreta, further assessment of placenta was performed using colourcoded flow and spectral Doppler flow. The highest peak velocity of pulsatile venous flow within the sonolucent placental vascular lakes was obtained using angle correlation and the resistance index of neovascularized arterial blood flow within the uterine serosa-posterior bladder wall boundary zone was recorded in definitely abnormal cases.

The colour Doppler criteria not suggestive of placenta accreta included the following:

- Discrete branching of surface chorionic arteries and intra placental villous arteries visualized within homogenous placental substance with typical flow velocity waveforms.

- Central cotyledonary sonolucent avillous cavities identified by real- time imaging containing a nonpulsatile low-velocity venous blood flow waveforms.

The colour Doppler criteria suggestive of placenta previa accreta included the following assessment:

- Diffuse lacunar flow pattern exhibiting diffusely dilated vascular channels scattered throughout the placenta and the surrounding myometrial or cervical tissues. High-velocity pulsatile venous-type flow was found in the sonolucent vascular spaces.

- Focal lacunar flow pattern showing irregular sonolucent vascular lakes with turbulent lacunar flow distributed regionally or focally within the intraparenchymal placental area.

- Interphase hypervascularity with abnormal blood vessels linking the placenta to the bladder with high diastolic arterial blood flow.

- Markedly dilated peripheral sub placental vascular channels with pulsatile venous type flow over the uterine cervix.

- Absence of sub placental vascular signals in the areas lacking the peripheral sub placental hypoechoic zone

The patients were prospectively followed till delivery. Intra-operative findings were noted and ultrasound findings were analysed with reference to the final diagnosis made during caesarean section. Histopathological examination of the uterus and placenta was done whenever a caesarean hysterectomy was carried out. The associated morbidities noted were as follows;

- Maternal Intra-operative complications: Estimated blood loss and transfusion requirements, bladder injury, PPH

- Maternal Post-operative complications: PPH, blood transfusions, duration of hospital stay, any mortality and others as fever, deep vein thrombosis, wound gaping.

- Fetal complications: Duration of NICU stay, significant neonatal morbidity, neonatal mortality.

\section{RESULTS}

The mean age of patients was 26.4 yrs (range $20-38$ yrs). 
The mean parity was 2.8. In our study, six out of hundred patients exhibited sonographic placental patterns suspicious for placenta accreta.
A summary of patient's history, colour Doppler features and outcome is shown in Table 1 .

Table 1: Summary of patient history, colour Doppler imaging (CDI) features and outcome of six cases of placenta accreta.

\begin{tabular}{|c|c|c|c|c|c|c|c|c|c|c|c|}
\hline $\begin{array}{l}\text { Obstetric } \\
\text { code }\end{array}$ & $\begin{array}{l}\text { Prior } \\
\text { Surgery }\end{array}$ & $\begin{array}{l}\text { Gestational } \\
\text { age at } \\
\text { diagnosis } \\
\text { (weeks) }\end{array}$ & $\begin{array}{l}\text { CDI } \\
\text { features }\end{array}$ & $\begin{array}{l}\text { Gestational } \\
\text { age at } \\
\text { delivery } \\
\text { (weeks) }\end{array}$ & Indication & $\begin{array}{l}\text { Estimated } \\
\text { blood loss } \\
\text { \& BTs }\end{array}$ & $\begin{array}{l}\text { Operative } \\
\text { Management }\end{array}$ & $\begin{array}{l}\text { Other } \\
\text { complications }\end{array}$ & $\begin{array}{l}\text { Neonatal } \\
\text { outcome } \\
\text { (gram) \& } \\
\text { Apgar } \\
\text { score }\end{array}$ & $\begin{array}{l}\text { NICU } \\
\text { stay }\end{array}$ & $\begin{array}{l}\text { Final } \\
\text { pathology } \\
\text { of } \\
\text { placenta }\end{array}$ \\
\hline G4P3L2 & 1 & 33 & $\begin{array}{l}\text { Focal LF } \\
\text { U-B } \\
\text { hyper- } \\
\text { vasculari } \\
\text { ty }\end{array}$ & 36 & Elective & $\begin{array}{l}1.5-21 \\
3 \text { units } \\
\text { BT }\end{array}$ & $\mathrm{CH}$ & $\begin{array}{l}\text { Bladder } \\
\text { injury }\end{array}$ & $\begin{array}{l}2400 \\
\mathrm{gm} \\
7 / 8\end{array}$ & $\begin{array}{l}1 \\
\text { day }\end{array}$ & Percreta \\
\hline G2P1L1 & None & 32 & $\begin{array}{l}\text { Diffuse } \\
\text { LF }\end{array}$ & 33 & $\mathrm{APH}$ & $\begin{array}{l}2-2.81 \\
4 \text { units } \\
\text { BT }\end{array}$ & $\mathrm{CH}$ & None & $\begin{array}{l}2000 \\
\mathrm{gm} \\
6 / 8\end{array}$ & $\begin{array}{l}6 \\
\text { days }\end{array}$ & Accreta \\
\hline $\begin{array}{l}\text { G4P2L1 } \\
\text { A1 }\end{array}$ & $\begin{array}{l}2 \\
\text { LSCS } \\
1 \mathrm{D} \\
\text { and C }\end{array}$ & 34 & Focal LF & 36 & Elective & $\begin{array}{l}1.2-1.51 \\
3 \text { units } \\
\text { BT }\end{array}$ & $\begin{array}{l}\text { Bilateral } \\
\text { uterine artery } \\
\text { ligation } \\
\text { Attempt to } \\
\text { remove } \\
\text { placenta } \\
\text { defect over } \\
\text { sewn }\end{array}$ & None & $\begin{array}{l}2750 \\
\text { gm } \\
8 / 9\end{array}$ & - & Accreta \\
\hline G3P2L2 & $\begin{array}{l}2 \\
\text { LSCS }\end{array}$ & 32 & $\begin{array}{l}\text { Dilated } \\
\text { SPC }\end{array}$ & 37 & Elective & $\begin{array}{l}1-1.21 \\
2 \text { units } \\
\text { BT }\end{array}$ & $\mathrm{CH}$ & None & $\begin{array}{l}2800 \\
\mathrm{gm} \\
7 / 8\end{array}$ & $\begin{array}{l}1 \\
\text { day }\end{array}$ & Increta \\
\hline G2P1L1 & 1 & 31 & $\begin{array}{l}\text { Focal LF } \\
\text { U-B } \\
\text { hyper- } \\
\text { vascularity }\end{array}$ & 32 & APH & $\begin{array}{l}2-2.51 \\
4 \text { units } \\
\text { BT }\end{array}$ & $\mathrm{CH}$ & $\begin{array}{l}\text { Bladder } \\
\text { injury }\end{array}$ & $\begin{array}{l}2100 \\
\text { gm } \\
6 / 7\end{array}$ & $\begin{array}{l}7 \\
\text { days }\end{array}$ & Percreta \\
\hline $\begin{array}{l}\text { G4P2L2 } \\
\text { A1 }\end{array}$ & $\begin{array}{l}1 \\
\text { LSCS } \\
1 \mathrm{D} \\
\text { and C }\end{array}$ & 30 & $\begin{array}{l}\text { Diffuse } \\
\text { LF }\end{array}$ & 36 & Elective & $\begin{array}{l}2-2.51 \\
4 \text { units } \\
\text { BT }\end{array}$ & $\mathrm{CH}$ & None & $\begin{array}{l}2850 \\
\text { gm } \\
8 / 9\end{array}$ & - & Accreta \\
\hline
\end{tabular}

LSCS: Lower segment Caesarean section, LF: Lacunar flow, U-B: Uterus bladder interface, SPC: Sub-placental venous channels, D \& C: Dilatation \& Curettage, BT: Blood transfusion, CH: Caesarean Hysterectomy

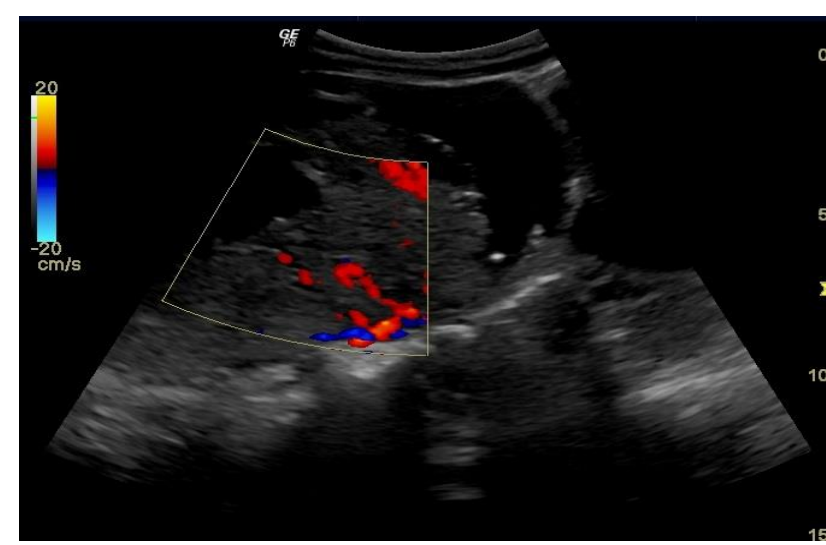

Figure 1: Color Doppler showing diffuse type of lacunar flow and extensive vascularity throughout the whole placenta and surrounding myometrial tissue.

All abnormally adherent placentas were predominantly anterior or central placenta previa and were correctly identified. The mean parity of these patients was 1.8 and mean gestational age at time of diagnosis was 32 weeks (range 30-34 weeks). Five out of six patients in the group suspicious for accreta had history of caesarean section. The mean gestational age at delivery was 35 weeks (range 32-37 weeks).

Among the six patients having CDI features of abnormally adherent placenta, two had diffuse type of lacunar flow and extensive vascularity throughout the whole placenta and surrounding myometrial tissue (Figure 1), one had focal lacunar flow within the suspicious region.

Two had focal lacunar flow along with marked vascularity within the uterine serosa-bladder junction and focal placental area (Figure 2). One patient had markedly dilated venous channels within the sub placental hypoechoic zone. In terms of operative management, peripartum caesarean hysterectomy was done in five out of six patients to control massive intra-operative bleeding. 


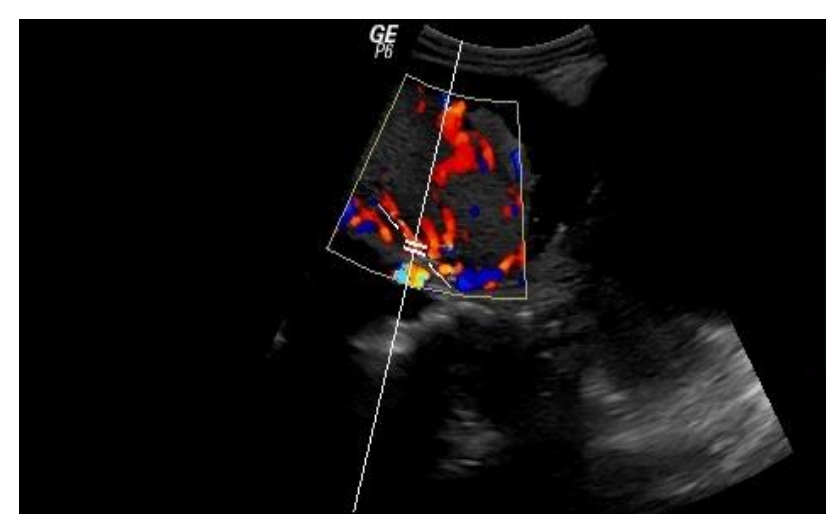

Figure 2: Color Doppler showing focal lacunar flow along with marked vascularity within the uterine serosa-bladder junction and focal placental area.

One patient with focal adherent piece of placenta of $2 \times 2$ $\mathrm{cm}$ underwent bilateral uterine artery ligation and did not require caesarean hysterectomy. The patient was followed up until 6 weeks postnatal and did not have any complication. Histopathological confirmation was done in all cases and it revealed chorionic villi penetrating to variable depths into the myometrium. Three patients had placenta accreta, one patient had increta and two had percreta.

Table 2: Efficacy of color Doppler imaging in prediction of placenta accrete.

\begin{tabular}{|llll|}
\hline CDI & \multicolumn{2}{l}{$\begin{array}{l}\text { Intraoperatively abnormally } \\
\text { adherent placenta (accreta, }\end{array}$} & Total \\
Features & $\begin{array}{l}\text { increta, percreta) } \\
\text { Present }\end{array}$ & Absent & \\
\hline Positive & 6 (true +ve) & 0 (false +ve) & 6 \\
\hline Negative & 0 (false -ve) & 94 (true -ve) & 94 \\
\hline Total & 6 & 94 & 100 \\
\hline
\end{tabular}

The mean estimated blood loss among patients with lacunar flow was $2100 \mathrm{ml}$ (range $1200-2800 \mathrm{ml}$ ) while that among patients with non-lacunar flow was $1100 \mathrm{ml}$ (range $1000-1200 \mathrm{ml}$ ). All patients required blood transfusions. Two patients had operative complication in terms of bladder injury. There was no long term maternal morbidity and no maternal mortality. The average birth weight of neonates was 2483grams (range 2000 2850 grams) and there was no neonatal mortality.

The remaining patients with placenta praevia not suspicious for placenta accreta underwent uncomplicated caesarean section. In our study, the sensitivity of colour Doppler imaging in prediction of placenta accreta was $100 \%(6 / 6)$ and specificity $100 \%$ (94/94). There were no false positive and false negative cases. The positive and negative predictive values both were $100 \%$ (Table 2). We also found that presence of lacunar flow predicted a higher incidence of blood loss, transfusion requirements and need for caesarean hysterectomy compared to patients with nonlacunar flow.

\section{DISCUSSION}

Placenta accreta is the abnormal adherence of a part or whole of placenta to the uterine wall as either accrete, increta or percreta depending on the extent of myometrial invasion. It is a potentially life threatening condition associated with massive haemorrhage often requiring hysterectomy, with severe complications such as bladder injury, ureteral injury, multiple blood transfusions, DIC, ICU care etc. Prenatal diagnosis with adequate preparation for the surgical management of this condition electively can prevent complications of catastrophic haemorrhage. Sonography is an effective screening tool for antenatal diagnosis of abnormally adherent placenta. Previous reports have emphasized use of conventional Bmode gray scale sonographic assessment for its prediction. Finberg and Williams, in their study found that gray-scale ultrasound had a sensitivity of $93 \%$ and specificity of $79 \% .^{9}$ The advent of Colour Doppler improved the diagnostic accuracy of conventionalgrayscalesonography. $5,7,8$

The colour Doppler criteria suggestive of placenta accrete have been first described by Chou et al. ${ }^{8}$ They include:

- A diffuse lacunar flow pattern exhibiting diffusely dilated vascular channels scattered throughout the whole placenta and the surrounding myometrial or cervical tissues. High-velocity pulsatile venous-type flow was found in the sonolucent vascular spaces.

- Interphase hypervascularity with abnormal blood vessels linking the placenta to the bladder with high diastolic arterial blood flow.

- A focal lacunar flow pattern showing irregular sonolucent vascular lakes with turbulent lacunar flow distributed regionally or focally within the intraparenchymal placental area.

- Absence of subplacental vascular signals in the areas lacking the peripheral subplacental hypoechoic zone.

- Markedly dilated peripheral subplacental vascular channels with pulsatile venous-type flow over the uterine cervix. Its sensitivity in the diagnosis of placenta accreta was $82.4 \%$ and specificity was $96.8 \%$ with positive and negative predictive values of $87.5 \%$ and $95 \%$ respectively.

Lerner and colleagues reported a sensitivity and specificity of $100 \%$ and $94 \%$ respectively. ${ }^{5}$ Levine and colleagues in their study found a sensitivity and specificity of $86 \%$ and $92 \%$ respectively. ${ }^{7}$ In present study, the sensitivity of colour Doppler imaging in prediction of placenta accreta was $100 \%(6 / 6)$ and specificity $100 \%$ (94/94). There were no false positive and false negative cases. The positive and negative predictive values both were $100 \%$ (Table 2).

In present study, we found that the variable vascular morphological manifestations of placenta accreta were exhibited that could be correctly identified by colour Doppler ultrasound. All our confirmed cases had at least 
one positive feature with colour Doppler ultrasound examination. A greater specificity with better assessment of the depth of myometrial and serosal invasion is the main advantage of adding colour Doppler to conventional grey scale ultrasound. The abnormal utero placental hyper vascularity caused by the angiogenesis of placental invasion can be detected with a high level of confidence.

First reported by Guy et al, the presence of lacunae within the placental parenchyma, particularly when concentrated to lower uterine segment, appears to be a separate risk factor for placenta accreta. ${ }^{10}$ These authors noted visible pulsatile flow in them and suggested that this implied transmission of high pulse pressure from the deep arterial system. Our study indicated that if the colour Doppler showed a diffuse lacunar flow pattern with high velocity pulsatile venous-type flow in the sonoluscent vascular spaces, there was a significant risk of life-threatening haemorrhagic complication. Twickler et al mapped colour flow in 20 cases of Placenta accreta using only ultrasound to evaluate turbulent lacunar blood flow. They found that all cases of Placenta accreta had turbulent flow in placental lacunae. ${ }^{11}$

In present study patients with CDI features of uterineserosa-bladder interphase hyper vascularity had bladder injury, hence urological assessment including cystoscopy and pre or intraoperative placement of a ureteral stent should be considered to facilitate recognition of the ureters and prevent the ureteral injuries. ${ }^{12}$

\section{CONCLUSION}

In conclusion, we found that colour doppler findings further validated the conventional grey-scale sonographic features. The extent and severity of haemodynamic changes of the utero placental circulation in placenta accreta must be taken into account and each case must be managed individually according to the variable vascular morphological patterns which are detected and categorised by colour Doppler ultrasound.

Funding: No funding sources Conflict of interest: None declared

Ethical approval: Not required

\section{REFERENCES}

1. Zorlu CG, Turan C, Islik AZ, Danisman N, Mungan $\mathrm{T}$, Gokmen O. Emergency hysterectomy in modern obstetric practice. Acta Obset Gynecol Scand. 1998;77:186-90.
2. Silver RM, Landon MB, Rouse DJ, Leveno KJ, Spong CY, Thom EA et al. Maternal morbidity associated with multiple repeat cesarean deliveries. Obstet Gynecol 2006;107:1226-32.

3. Usta IM, Hobeika EM, Musa AA, Gabriel GE, Nassar AH. Placenta previa-accreta: risk factors and complications. Am J Obstet Gynecol. 2005;193:1045-9.

4. Lam G, Kuller J, McMahon M. Use of magnetic resonance imaging and ultrasound in the antenatal diagnosis of placenta accreta. J Soc Gynecol Invest. 2002;9:37-40.

5. Lerner JP, Deane S, Timor-Tritsch IE. Characterization of placenta accreta using transvaginal sonography and colour Doppler imaging. Ultrasound Obstet Gynecol. 1995;5:198201.

6. American College of Obstetricians and Gynecologists. Placenta accreta: committee opinion no. 529. Obstet Gynecol. 2012;120:207-211.

7. Levine D, Hulka CA, Ludmir J, Li W, Edelman RR. Placenta accreta: evaluation with colour Doppler US, power Doppler US, and MR imaging. Radiology 1997;205(3):773-6.

8. Chou MM, Ho ES, Lee YH. Prenatal diagnosis of placenta previa accreta by transabdominal colour Doppler ultrasound. Ultrasound Obstet Gynecol. 2000;15:28-35.

9. Finberg HJ, Williams JW. Placenta accreta; prospective sonographic diagnosis in patients with placenta previa and prior caesarean section. J Ultrasound Med. 1992;11:333-43.

10. Guy G, Peisner DB, Timor-Tritsch IE. Ultrasonographic evaluation of uteroplacental blood flowpatterns of abnormally located and adherent placentas. Am J Obstet Gynecol. 1990;163:723-7.

11. Twickler DM, Lucas MJ, Balis AB, Santos-Ramos $\mathrm{R}$, Martin L, Malone $\mathrm{S}$ et al. Colour flow mapping for myometrial invasion in women with a prior cesarean delivery. J Matern Fetal Med. 2000;9:3305.

12. Silver LE, Hobel CJ, Lagasse L, Luttrull JW, Platt LD. Placenta previa percreta with bladder involvement; new considerations and review of the literature. Ultrasound Obstet Gynecol. 1997;9:131-8.

Cite this article as: Agarwal R, Bhaskaran S, Gupta E, Dutta D, Tandon A. Efficacy of colour doppler imaging in prediction of placenta accrete. Int $\mathbf{J}$ Reprod Contracept Obstet Gynecol 2017;6:4377-81. 